\title{
Aptamer-Based Electrochemical Sensing of Lysozyme
}

\author{
Alina Vasilescu ${ }^{1, *}$, Qian Wang ${ }^{2,3}$, Musen Li ${ }^{3}$, Rabah Boukherroub ${ }^{2}$ and Sabine Szunerits ${ }^{2, *}$ \\ 1 International Center of Biodynamics, 1B Intrarea Portocalelor, Sector 6, Bucharest 060101, Romania \\ 2 Institute of Electronics, Microelectronics and Nanotechnology (IEMN), UMR CNRS 8520, Lille1 University, \\ Avenue Poincaré-BP60069, Villeneuve d'Ascq 59652, France; qianwang0628@gmail.com (Q.W.); \\ rabah.boukherroub@univ-lille1.fr (R.B.) \\ 3 Key Laboratory for Liquid-Solid Structural Evolution and Processing of Materials, Shandong University, \\ Jinan 250061, China; msli@sdu.edu.cn \\ * Correspondence: avasilescu@biodyn.ro (A.V.); sabine.szunerits@univ-lille1.fr (S.S.); \\ Tel.: +40-21-310-4354 (A.V.); +33-3-6-253-1725 (S.S.)
}

Academic Editors: Paolo Ugo and Ligia Moretto

Received: 10 March 2016; Accepted: 8 June 2016; Published: 14 June 2016

\begin{abstract}
Protein analysis and quantification are required daily by thousands of laboratories worldwide for activities ranging from protein characterization to clinical diagnostics. Multiple factors have to be considered when selecting the best detection and quantification assay, including the amount of protein available, its concentration, the presence of interfering molecules, as well as costs and rapidity. This is also the case for lysozyme, a 14.3-kDa protein ubiquitously present in many organisms, that has been identified with a variety of functions: antibacterial activity, a biomarker of several serious medical conditions, a potential allergen in foods or a model of amyloid-type protein aggregation. Since the design of the first lysozyme aptamer in 2001, lysozyme became one of the most intensively-investigated biological target analytes for the design of novel biosensing concepts, particularly with regards to electrochemical aptasensors. In this review, we discuss the state of the art of aptamer-based electrochemical sensing of lysozyme, with emphasis on sensing in serum and real samples.
\end{abstract}

Keywords: lysozyme; aptamers; surface modification; electrochemical methods

\section{Introduction}

\subsection{Properties of Lysozyme and Its Importance for Daily Life}

Discovered by Laschtschenko in 1909 [1] and named by Fleming in 1922 [2], lysozyme is a remarkable protein. Also called muramidase or peptidoglycan $N$-acetylmuramoyl-hydrolase, lysozyme is a ubiquitous enzyme (EC 3.2.1.17) present in various organisms [3-5], where it plays a vital role (Figure 1). Next to some of its physico-chemical features, such as a high isoelectric point of 10-11, a positive charge at neutral $\mathrm{pH}$, excellent heat stability and stability in acid media [3], its antibacterial activity plays an important role in the defense system in the human body [6], lysozyme being suggestively called the body's own antibiotic.

Lysozyme was also the first enzyme whose tridimensional structure was solved [7], showing a globular structure with dimensions of $4.5 \times 3.0 \times 0.3 \mathrm{~nm}$ and a relatively small molecular weight of approximately $14.3 \mathrm{kDa}$ (human lysozyme is $14.6 \mathrm{kDa}$ ). It is found as a single polypeptide chain consisting of 129-130 amino acid residues, in which lysine is the N-end amino acid and leucine the C-end one. All of this together has made lysozyme a good model to study enzyme catalysis, protein structure and interactions [8-11] or amyloid-fibrillation formation [12-14]. Lysozyme from hen egg has become also a model protein for the pharmaceutical industry when it comes to the development of new drug delivery systems or the design of innovative treatment strategies [15-17] (Figure 1). 


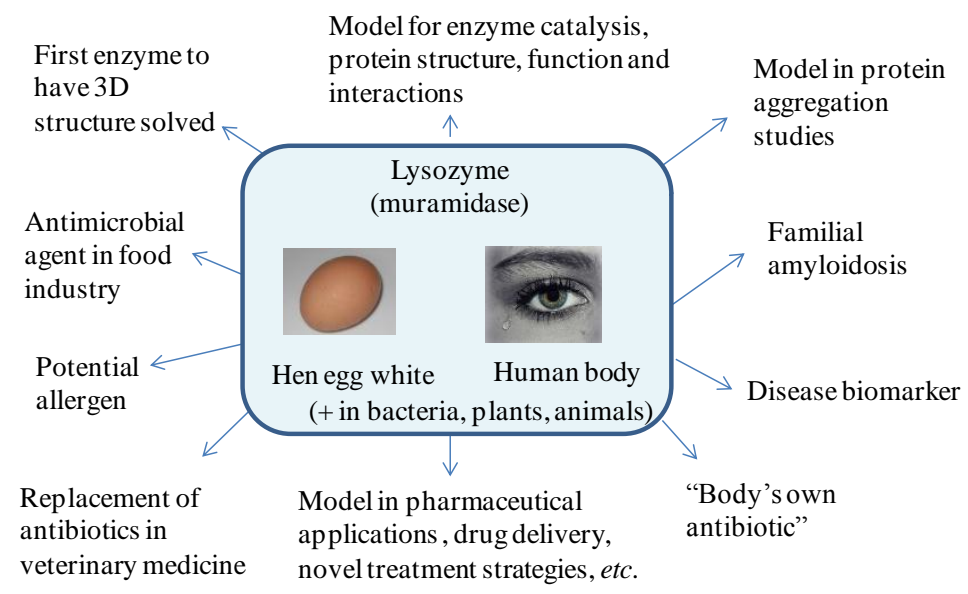

Figure 1. The relevance of lysozyme for protein science, medicine and industrial applications.

A rich and easily available source of lysozyme is the egg white of birds. In the hen egg white, lysozyme accounts for $3.5 \%$ of the total egg white proteins. Hen egg lysozyme, considered as a safe product by authorities in different countries (Austria, Australia, Belgium, Denmark, Finland, France, Germany, Italy, Japan, Spain and the United Kingdom) with antibacterial action, has been used for many years as a food preservative [4]. A major commercial use of lysozyme is in the production of some types of hard cheese, where its addition prevents the growth of butyric bacteria [18,19]. In the wine industry, lysozyme partially replaces sulfites and is added at doses of $250-500 \mathrm{mg} / \mathrm{L}$ to inhibit malolactic fermentation and to stabilize the wine afterwards [20,21]. Residual levels of $0.06-327 \mathrm{mg} / \mathrm{L}$ were found in lysozyme-treated wines [22,23], while in commercial cheeses, concentrations of $30.8-386.2 \mathrm{mg} / \mathrm{kg}$ were found to be present [24]. Lysozyme has also been used as an antibacterial agent during beer production [25], to extend the shelf-life of meat [26] and shrimp [27], as an alternative to antibiotics [28,29] in veterinary medicine or as anti-inflammatory drug in the treatment of wounds and infections $[4,30]$.

Despite its proven utility, lysozyme can potentially trigger allergic reactions in sensitive individuals, even in trace amounts [21]. Consequently, appropriate labeling rules have been established by regulatory agencies for products containing egg white lysozyme. The importance of lysozyme sensing in real samples is furthermore associated with human lysozyme being identified as an important biomarker for several diseases [31].

In the human body, lysozyme is indeed widely distributed in tissues and body fluids with the lowest levels found in urine (1.7-123 ng/mL) [32] and cerebrospinal fluid (7.7-84 $\mu \mathrm{g} / \mathrm{L})$ [33] and the highest in gastric juice or mothers' milk (300 mg/L) [34] and tears (1267 $\pm 58 \mathrm{mg} / \mathrm{L})$ [35]. In the serum of healthy people, concentrations in the range of $0.462-2.958 \mathrm{mg} / \mathrm{L}$ have been reported [33,35].

Increased levels of lysozyme in serum are an expression of monocyte/macrophage activity [36] and were identified in various diseases, such as AIDS [37], pulmonary tuberculosis [38], sarcoidosis [39], rheumatoid arthritis [40] and Crohn's disease [41]. Additionally, the concentration of lysozyme in cerebrospinal fluid helps distinguishing between viral and bacterial meningitis, with high lysozyme levels pointing towards bacterial meningitis [33]. Urinary lysozyme levels have become an indicator of damage to renal tubular cells with diagnostic value in monocytic or myelomonocytic leukemia $[42,43]$. However, only a few reports show the sensitivity and selectivity required for sensing in real biological samples, achieved using different signal amplification strategies [44-47].

\subsection{Quantification Methods}

The classical method for determining lysozyme is based on the ability of lysozyme to clear a suspension of Micrococcus lysodeikticus cells [31]. The activity of lysozyme in promoting the dissolution of the cell wall depends on its ability to catalyze the hydrolysis of the $\beta$-(1,4)-glycosidic linkage between $\mathrm{N}$-acetyl-D-glucosamine in the polysaccharide component of the bacterial cell wall. 
The decrease in turbidity correlates with the lysis of the cell wall and is recorded either by the 'lysoplate' method or by turbidimetric assays [31]. These approaches allow the quantification of $<1 \mathrm{ng}$ lysozyme. However, the evaluation of the enzymatic activity needs a strict control of temperature, $\mathrm{pH}$ and ionic strength; moreover, it is time consuming. The sensitivity of this method is strongly dependent on the assay conditions and the presence of other substances in the samples that affect the interaction of lysozyme with the medium. More recently, we developed a novel assay to sense lysozyme in serum using Micrococcus lysodeikticus-modified graphene oxide-coated surface plasmon resonance (SPR) interfaces [48]. In this approach, graphene oxide (GO) is integrated onto gold interfaces using layer-by-layer deposition of a polycationic polymer and GO. Adsorption of whole cells of Micrococcus lysodeikticus onto GO and blocking remaining GO sites with BSA (3\%) gave a reproducible non-fouling surface for the sensing of lysozyme in serum samples. The detection mechanism is based on a sensitive monitoring of lysozyme-dependent desorption of Micrococcus lysodeikticus cells from the sensor surface. This desorption, together with a significant change in morphology of the bacterial cell, causes a characteristic decrease of the SPR signal with a limit of detection of $0.05 \mu \mathrm{g} \cdot \mathrm{mL}^{-1}$ [48].

Other methods based on the quantification of the protein amount and not its enzymatic activity have been reported, including electrophoretic [49], chromatographic [50,51] and immunoenzymatic methods [52]. The ELISA technique is particularly promising for its high sensitivity, high specificity and convenience, especially for the analysis of a large number of samples $[53,54]$ with a detection limit around $0.2 \mu \mathrm{g}$ lysozyme/L.

Next to these approaches, in recent years, a few aptamer-based analytical methods have been developed towards lysozyme recognition and detection [47,55-63]. Aptamers are small single-stranded oligonucleotides (DNA or RNA) that are selected in vitro to bind with high affinity and specificity any selected target of choice, from small-sized, such as metal ions [64], to large ones, such as cells [65]. Since aptamers possess numerous advantages over antibodies, such as high stability, resistance to denaturation and degradation, as well as easy modification possibilities, they have found widespread uses for bioanalysis $[56,66,67]$. One of the particularities of aptamers is the fact that their affinities are not affected by labeling, offering thus generous opportunities for protein sensor designs with improved analytical performances.

The ionic charge of lysozyme renders the protein suitable for the specific binding to DNA aptamers. The first publications dealing with anti-lysozyme aptamers, selected by systematic evolution of ligands by exponential enrichment (SELEX) are from Ellington and co-workers [68-70] (Table 1). Based on these results, Kirby et al. [70] have developed a reusable bead-based electronic tongue sensor arrays of anti-lysozyme aptamers for the detection of proteins, where fluorescence labeling is involved. Using capillary electrophoresis-SELEX, a new lysozyme aptamer characterized by an order of magnitude increased affinity was selected (Table 1) [71]. Based on these new bioreceptors, electrochemical sensors emerged as alternative devices able to offer alternative lysozyme sensing strategies. Electrochemical biosensors represent a commercially-proven concept, capable of delivering sensitive, miniaturized and cost-effective detection of relevant analytes. Together with thrombin, lysozyme is widely used as a model analyte for developing new electrochemical aptasensor assays. The opportunities brought by electrochemical aptasensors for the bioanalysis of lysozyme are discussed in this review, putting emphasis on their use for practical applications, particularly for lysozyme analyses in serum.

Table 1. DNA sequence of different lysozyme aptamers.

\begin{tabular}{lcc}
\hline \multicolumn{1}{c}{ DNA Sequence } & $\mathbf{K}_{\mathbf{d}} \mathbf{n} \mathbf{M}$ & Reference $^{-}$ \\
\hline 5'-ATCAGGGCTAAAGAGTGCAGAGTTACTTAG-3' $^{\prime}$ & 31 & {$[68]$} \\
\hline 5'-GGGAATGGATCCACATCTACGAATTCATCAGGGCTAAAGAG $^{\prime}$ & $29 \pm 5$ & {$[70]$} \\
\hline TGCAGAGTTACTTAGTTCACTGCAGACTTGACGAAGCTT-3' & & \\
\hline 5'-GCAGCTAAGCAGGCGGCTCACAAAACCATTCGCATGCGGC-3' & $2.8 \pm 0.3$ & {$[71]$} \\
\hline
\end{tabular}




\section{Aptamer-Based Electrochemical Lysozyme Sensors}

The main characteristics of the aptamers used in lysozyme biosensors are summarized in Table 1, starting from the first examples proposed by Ellington and co-workers [68,69], followed by Tran et al. [71]. By using electrochemical impedance spectroscopy (EIS) on screen-printed carbon electrodes [63], it was demonstrated that the lowest detection limit and wider linear range can be achieved using the aptamer proposed by Tran et al. [71]. More recent studies showed that using a mixture of two aptamer sequences with different affinities allows an improved control of the sensitivity and linear range of aptasensors [72]. Taking into account these developments, future aptasensors should include parallel experiments with more than one aptamer sequence present on the biosensor surface for achieving optimized sensing.

Various electrochemical aptasensors, based on different assay formats, aptamer construction strategies and detection methods have been developed for lysozyme sensing in samples, such as egg white, wine, saliva, urine, serum and cancer cells, as summarized in Table 2 (see also the relevant abbreviations' list at the end of the paper).

Table 2. Electrochemical aptasensors developed for lysozyme sensing.

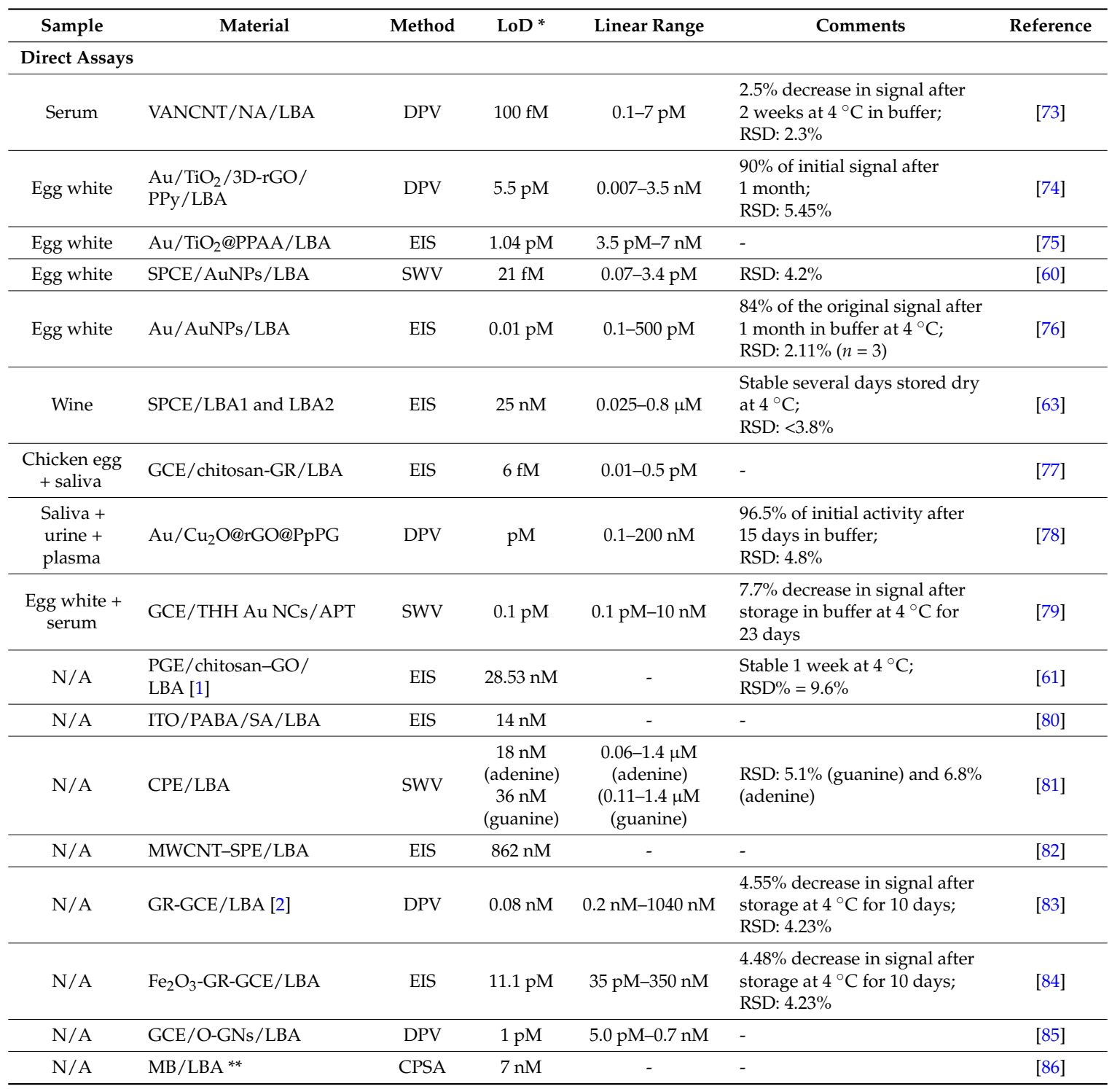


Table 2. Cont.

\begin{tabular}{|c|c|c|c|c|c|c|}
\hline Sample & Material & Method & LoD* & Linear Range & Comments & Reference \\
\hline $\mathrm{N} / \mathrm{A}$ & $\mathrm{Au} / \mathrm{LBA}$ & $\mathrm{CV}$ & - & $35 \mathrm{nM}-3.5 \mu \mathrm{M}$ & - & [87] \\
\hline N/A & $\begin{array}{l}\mathrm{ITO} /(\mathrm{Fc}-\mathrm{PEI} / \mathrm{CNTs} / \\
\mathrm{Fc}-\mathrm{PEI} / \mathrm{LBA})_{3}\end{array}$ & DPV & $11.8 \mathrm{pM}$ & $13.9 \mathrm{pM}-116 \mathrm{nM}$ & $\begin{array}{l}7.5 \% \text { decrease after } 24 \text { days at } \\
\text { room temperature in air; } 2.25 \% \\
\text { increase after } 21 \text { days in } \\
\text { distilled water at } 4{ }^{\circ} \mathrm{C}\end{array}$ & [88] \\
\hline \multicolumn{7}{|c|}{ Sandwich Assay } \\
\hline \multicolumn{7}{|c|}{ Competitive Assays } \\
\hline Serum & $\mathrm{Au} / \mathrm{CD} / \mathrm{DLAP} 1+\mathrm{DLAP} 2$ & DPV & $64 \mathrm{pM}$ & $100-1000 \mathrm{pM}$ & - & [89] \\
\hline Serum & $\mathrm{Au} / \mathrm{MeB}-\mathrm{cDNA} / \mathrm{LBA}$ & SWV & $16.4 \mathrm{pM}$ & $0.1-100 \mathrm{nM}$ & $\begin{array}{l}\text { Stable } 3 \text { weeks at } 4{ }^{\circ} \mathrm{C} ; \\
\text { RSD: }<5 \%\end{array}$ & [90] \\
\hline Egg white & $\mathrm{Au} / \mathrm{cDNA} / \mathrm{LBA}$ & LSW & $1 \mathrm{pM}$ & $1.0 \mathrm{pM}-1.1 \mathrm{nM}$ & RSD $<4.2 \%(n=5)$ & [92] \\
\hline $\begin{array}{c}\text { Ramos } \\
\text { cancer cells }\end{array}$ & $\begin{array}{l}\text { DNA machine, } \\
\text { CdS NP-DNA/LBA ** }\end{array}$ & DPASV & $0.52 \mathrm{pM}$ & $1 \mathrm{pM}-80 \mathrm{nM}$ & $\mathrm{RSD}<6.1 \%(n=3)$ & [93] \\
\hline N/A & $\begin{array}{l}\mathrm{Au} / \mathrm{TBA} \text { and LBA/ } \\
\text { (PbS-Lys and CdS-Thr) }\end{array}$ & SWV & - & $\begin{array}{l}75 \% \text { signal } \\
\text { decrease for } \\
0.07 \mathrm{nM}\end{array}$ & - & [94] \\
\hline $\mathrm{N} / \mathrm{A}$ & $\begin{array}{l}\text { Au/DNA1/BiDNA/ } \\
\text { DNA3-AuNPs }\end{array}$ & $\mathrm{CV}$ & $0.7 \mathrm{nM}$ & - & $\begin{array}{l}\text { Stable for } 2 \text { weeks in distilled } \\
\text { water at } 4{ }^{\circ} \mathrm{C} \text { RSD: } 4.6 \%\end{array}$ & [95] \\
\hline
\end{tabular}

* A molecular weight of $14.3 \mathrm{kDa}$ for lysozyme was used to convert concentration units from $\mathrm{g} / \mathrm{L}$ into $\mathrm{M}$; ${ }^{* *}$ not an aptasensor, but an aptamer-based assay with electrochemical detection; N/A: measurements done with lysozyme standard solutions in buffer.

\subsection{Surface Immobilization of Aptamer Ligands}

The immobilization of the analyte-specific ligand on the sensing interface is a key step to achieve selective detection [97]. The use of an efficient immobilization method is crucial to ensure adequate stability and optimum surface coverage, however, carefully avoiding lowering the affinity of the aptamer for its target. To ensure that $K_{d}$ is not affected upon aptamer immobilization, the effective dissociation constant of the immobilized aptamer-lysozyme complex should remain constant. For instance, in [90], for the immobilized aptamer, a $K_{d}$ value of $30 \mathrm{nM}$ was measured, which compared well with that measured in solution, namely $31 \mathrm{nM}$ [68].

The immobilization strategies used for aptamers for lysozyme are the following:

1. adsorption or $\pi-\pi$ stacking interactions between the DNA bases of the lysozyme aptamer and graphene oxide-modified interfaces (Figure 2A) [83-85]

2. covalent linkage of the aptamer to carboxylic-acid functions present on the electrode surface (Figure 2B) $[44,63,77]$

3. binding of thiolated aptamers to gold electrodes or particles (Figure 2C) $[46,62,76,87,94]$

4. click chemistry between azide-modified gold particles and alkyne-terminated aptamers (Figure 2D) [60]

5. electrostatic interactions between the negatively-charged phosphate backbone of the aptamer and positively-charged materials (Figure 2E), such as polypyrrole, $\mathrm{Fe}_{2} \mathrm{O}_{3}$ and ferrocene-appended poly(ethyleneimine) (Fc-PEI) in a layer-by-layer approach or amine-rich films of plasma-polymerized propargylamine in a $\mathrm{Cu}_{2} \mathrm{O} @ \mathrm{rGO} @ \mathrm{PpPG}$-modified gold electrode $[74,78,84,88]$ 
6. affinity binding based on biotin-avidin [80] or host-guest interactions [89] (Figure 2F)

7. hybridization to a partially complementary DNA strand, previously immobilized on the electrode surface (Figure 2G) [96]

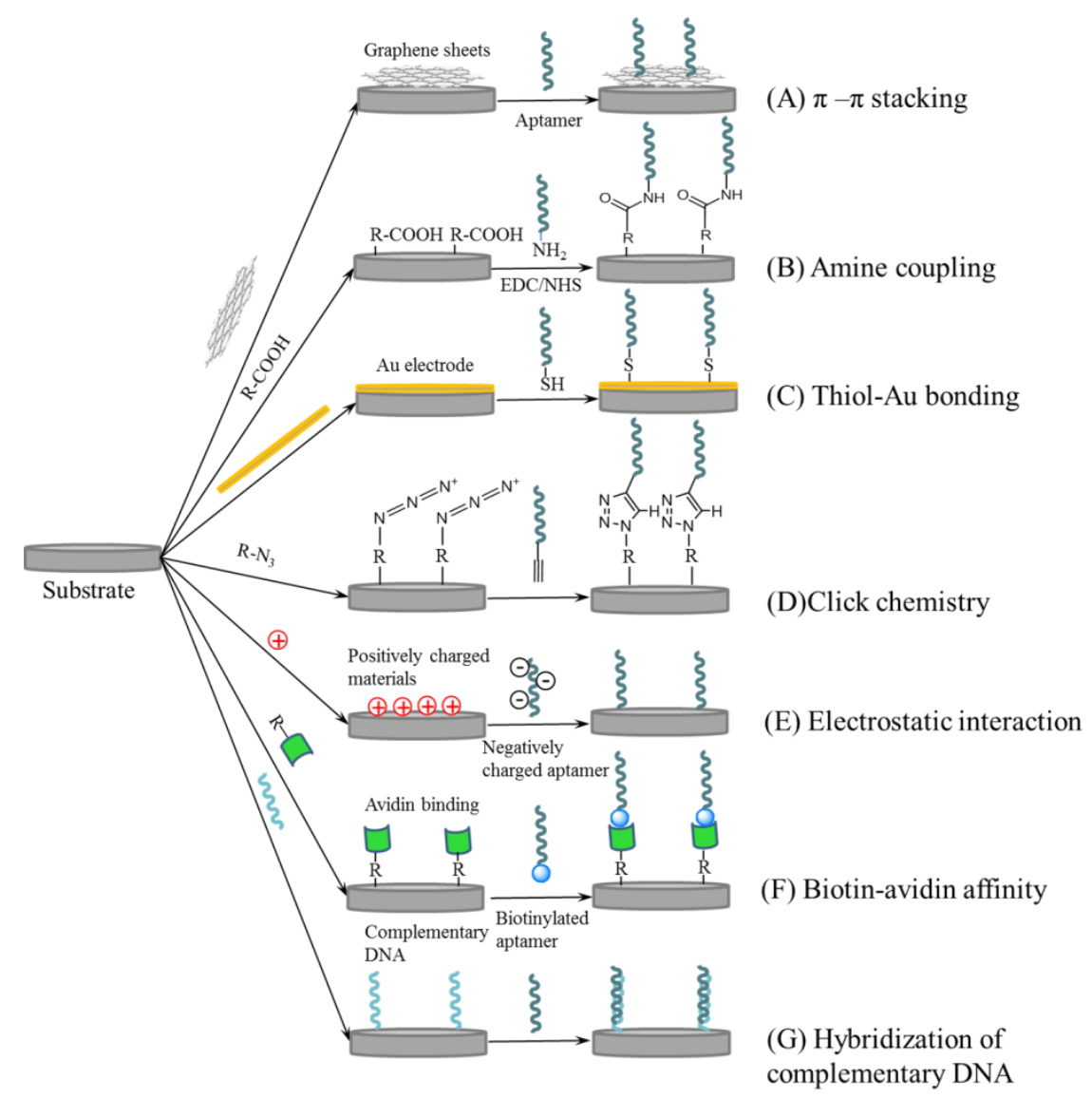

Figure 2. Schematic illustration of different strategies for the modification of electrical interfaces with aptamers.

For Case (1), polarization of carbon paste electrodes (CPE) at $+0.5 \mathrm{~V}$ for 2 min [81] or modification via drop casting with reduced graphene oxide ( $\mathrm{rGO}$ [ [83], $\mathrm{rGO} / \mathrm{Fe}_{2} \mathrm{O}_{3}$ or $\mathrm{rGO} /$ Orange II nanocomposites $[84,85]$ results in interfaces with the ability to strongly interact with aptamers via $\pi-\pi$ stacking.

For Strategy (2), an appropriate number of carboxylic functional groups can be introduced on the electrode surface by modification with nanocomposites of graphene oxide-chitosan [61,77], or reduction of diazonium salts of $p$-aminobenzoic acid on carbon electrodes [44,63], or by attaching vertically-aligned nitrogen-doped carbon nanotubes (VA-NCNTs) [73]. Rohrbach et al. modified screen-printed graphite electrodes with multi-walled carbon nanotubes (MWCNTs) containing about $5 \%$ carboxylic acid groups [82]. Another strategy relied on covering a Au electrode with hollow $\mathrm{TiO}_{2}$ spheres and a film of polyacrylic acid [75], where polyacrylic acid provided the carboxyl groups for aptamer immobilization, while the hollow $\mathrm{TiO}_{2}$ spheres enabled increased surface area for higher aptamer loading and improved electrical characteristics.

The majority of electrochemical aptasensors for lysozyme used thiolated aptamers on gold electrode, that is following Strategy (C) $[46,62,87,91,94]$. To increase the aptamer loading, a popular approach relies on modifying the electrodes with Au nanoparticles $[47,76]$.

By using click chemistry (Strategy D), Xie et al. used AuNPs electrodeposited on screen-printed graphite electrodes and modified with a self-assembled monolayer of 10-azidodecane-1-thiol [60], to 
form a "clickable" interface with alkyne-terminated lysozyme aptamers (see Figure 3A). Compared to direct immobilization of thiolated aptamers on the AuNPs-coated electrode, this approach allowed a 3.4-fold increase in the analytical signal for a concentration of $10 \mathrm{pg} / \mathrm{mL}$ lysozyme, so increasing the sensitivity of the sensor. The higher aptamer coverage $\left(3.3 \times 10^{11}\right.$ molecules cm $\mathrm{cm}^{-2}$ for aptamer "clicked" on SAM versus $2.2 \times 10^{11}$ molecules $\mathrm{cm}^{-2}$ for simple chemisorption of thiolated aptamer) was claimed to be the origin of the improved performances [60]. The potential of the "clickable" interface as generic support for an aptasensor array was further illustrated by efficient immobilization of three different aptamers (for lysozyme, cocaine and thrombin) [60].

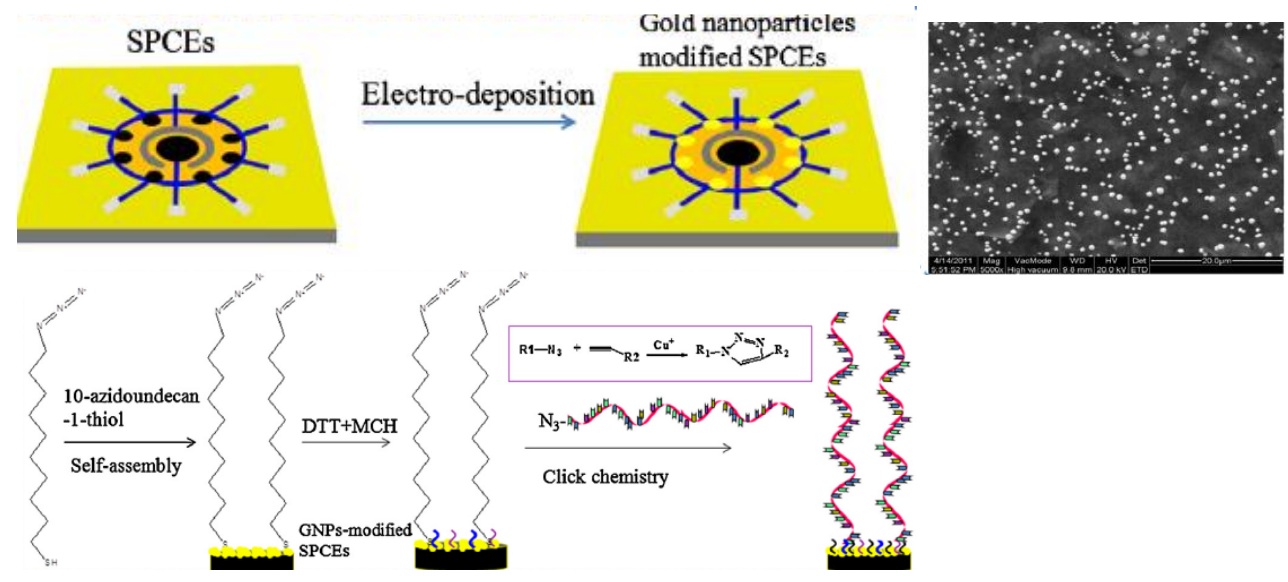

(A)
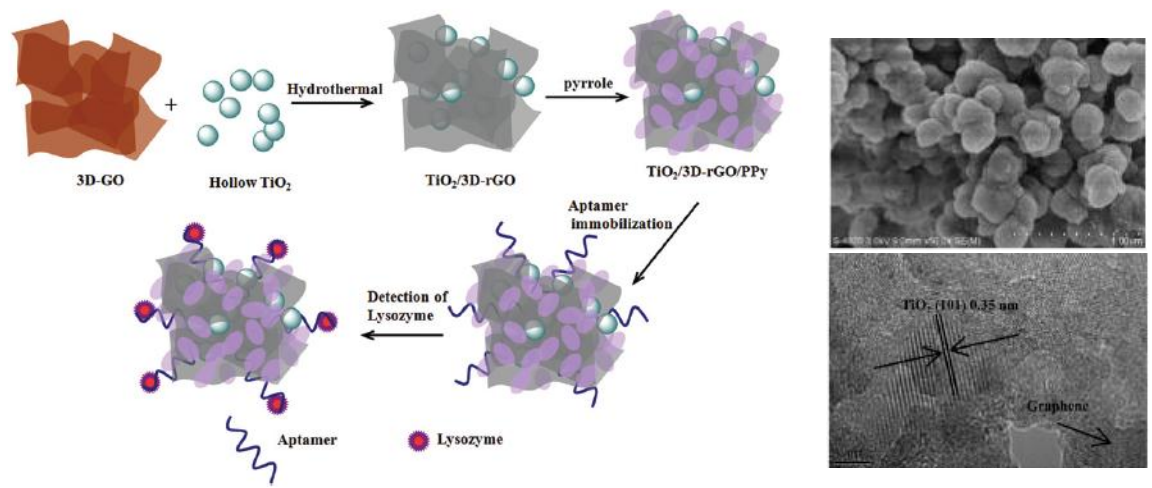

(B)

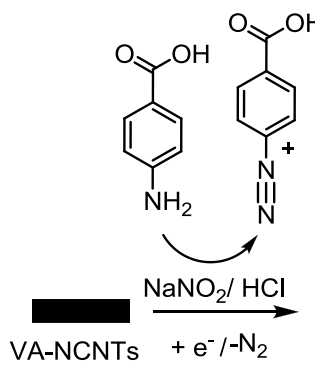

VA-NCNTS $+\mathrm{e}^{-/-\mathrm{N}_{2}}$
VA-NCNTs-COOH

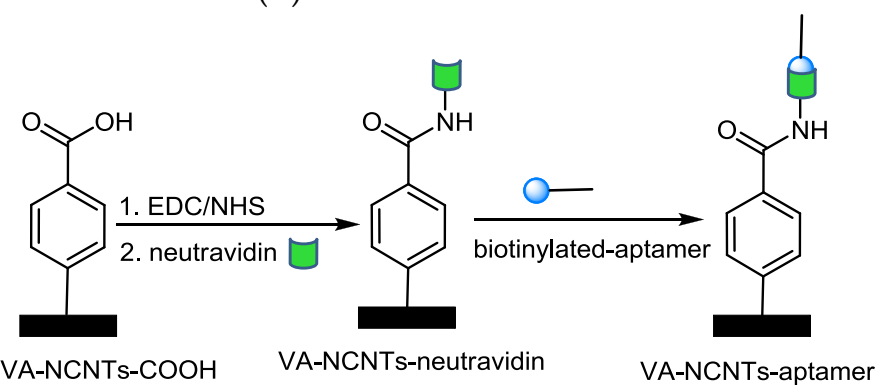

(B)

(C)

Figure 3. Cont. 


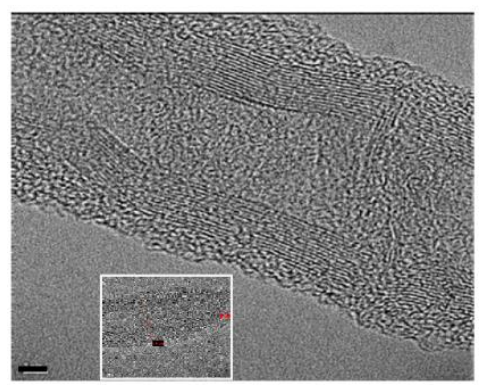

(D)

Figure 3. (A) Schematic of screen-printed electrodes modified with gold nanoparticles and subsequent surface modification (reprinted with permission from [60]); (B) schematic of $\mathrm{TiO}_{2} / 3 \mathrm{Dgraphene/polypyrrole} \mathrm{aptasensor} \mathrm{for} \mathrm{lysozyme} \mathrm{detection} \mathrm{together} \mathrm{with} \mathrm{SEM} \mathrm{and} \mathrm{TEM} \mathrm{images}$ of the nanocomposite (reprinted with permission from [74]); (C) surface modification of the VA-NCNT electrode through electroreduction of 4-carboxyphenyl diazonium salt formed in situ followed by covalent immobilization of neutravidin and interaction with the biotinylated lysozyme aptamer; (D) HRTEM image of modified VA-NCNTs (scale bar $2 \mathrm{~nm}$ ) [73].

More recently, electrodes modified with a $\mathrm{TiO}_{2} / 3 \mathrm{D}$ graphene/polypyrrole nanocomposite [74] proved to be an interesting alternative for lysozyme sensing. The aptamer was immobilized via a combination between $\pi-\pi$ stacking interactions with $3 \mathrm{D}$ graphene (Figure $2 \mathrm{~A}$ ) and adsorption onto the positively-charged polypyrrole (Figure 2E). The hollow $\mathrm{TiO}_{2}$ spheres provided a large surface, porous support for 3D-graphene and polypyrrole, acting synergistically with these two materials to facilitate the immobilization of significant amounts of aptamer (Figure 3B).

Affinity interactions (Case F) were exploited for attaching a labeled lysozyme aptamer to an electrode either firmly, by taking advantage of strong biotin-avidin binding (Figure 2F) or more loosely via host-guest interactions. In the case of VA-NCNTs, a detection limit as low as $100 \mathrm{fM}$ with a linear range up to $7 \mathrm{pM}$ could be achieved by first grafting 4-carboxyphenyl radicals to the VA-NCNTs using a standard procedure involving the reduction of 4-carboxybenzenediazonium cations to generate aryl radicals (Figure 3C), followed by neutravidin linking and integration with biotinylated lysozyme aptamers. Interestingly, this strategy results in a functionalized layer both on the lateral sides and tip (Figure 3D) of the carbon nanotubes, suggesting that VA-NCNTs are uniformly modified throughout their length, which might be one of the reasons for their high sensitivity towards lysozyme.

A weaker binding between a dabcyl-labeled aptamer and a $\beta$-cyclodextrin-modified electrode via host-guest interactions (Figure $2 \mathrm{G}$ ) laid the basic principle for a multiple use aptasensor, where easy regeneration of the aptasensor surface was achieved simply by re-incubation with dabcyl-labeled aptamer after each lysozyme measurement [89].

\subsection{Electrochemical Assay Formats: Direct, Sandwich and Competitive Assays}

In order to translate the lysozyme-aptamer binding event into a measurable electrochemical signal, various techniques have been employed, including cyclic voltammetry (CV), differential pulse voltammetry (DPV), square wave voltammetry (SWV) or electrochemical impedance spectroscopy (EIS) using direct, sandwiched or competitive assays (Figure 4). Indeed, the formation of a lysozyme-aptamer complex leads to changes in the electrical properties at the sensor/solution interface, which translate into either an improvement or a hindered access of a reporter probe to the electrode surface. This is reflected quantitatively in a change in the charge transfer resistance at the interface, which can be determined by EIS, or a change in the magnitude of the oxidation/reduction current of the reporter probe, measurable by voltammetric methods (Figure 4). Voltammetric methods, such as SWV or DPV, are generally more sensitive [47]. They have also the advantage of delivering a unique "signature" of the electroactive species used as reporters based on their oxidation/reduction potential. Provided that 
their oxidation/reduction potentials are separated enough so that their electrochemical signals can be resolved, several electroactive labels have been used to detect multiple proteins with the same sensor. For instance, aptasensors for dual detection of lysozyme and interferon gamma [90] or thrombin [89,94] have been developed based on this principle.

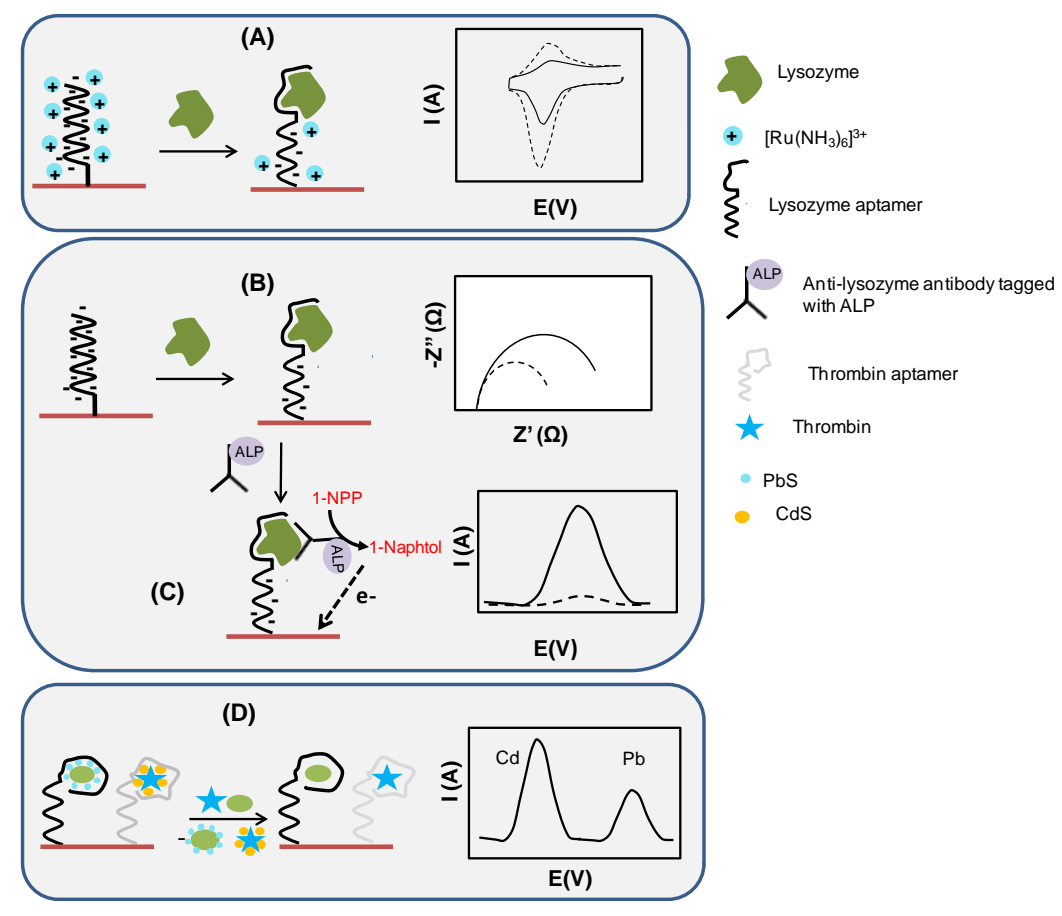

Figure 4. Electrochemical aptasensors' detection schemes of lysozyme: (A) direct assay by recording the conformational changes of surface-linked aptamers upon lysozyme binding, which results in a decrease in electrostatically-bound $\left.\mathrm{Ru}\left(\mathrm{NH}_{3}\right)_{6}\right]^{3+}$ detectable by CV (e.g., as illustrated in [87]); (B) formation of the aptamer-lysozyme complex creates a barrier for the electron transfer of $\left(\mathrm{Fe}(\mathrm{CN})_{6}\right]^{4-/ 3-}$ in solution proportional to lysozyme concentration and detectable by EIS [63]; (C) sandwich assay for lysozyme analysis using amplification with a lysozyme antibody labeled with alkaline phosphatase [44]; (D) competitive assay where free lysozyme in solution displaces quantum dot-tagged lysozyme, previously bound to surface-immobilized aptamer (e.g., as illustrated in [94]).

Positively-charged ruthenium hexamine used in [87] (Figure 4A) and negatively-charged ferricyanide are widely investigated for reporting on aptamer recognition events. Ruthenium hexamine binds electrostatically to the negatively-charged phosphate backbone of DNA. The magnitude of the reduction peak of $\left[\mathrm{Ru}\left(\mathrm{NH}_{3}\right)_{6}\right]^{3+}$ can be used to determine the amount of surface linked aptamer [87] and additionally can be a direct measure for lysozyme: the difference in current intensity due to $\left[\mathrm{Ru}\left(\mathrm{NH}_{3}\right)_{6}\right]^{3+}$ reduction before and after sensor incubation with lysozyme correlates with the concentration of lysozyme in the sample. Figure 5A shows one example of the direct detection of lysozyme on aptamer-modified interfaces using EIS [63]. The change in the electrical properties at the sensor/solution interface was exploited for a comparison of the analytical performances of two aptamers and quantitative detection with detection limits of $25 \mathrm{nM}$ for the aptamer selected by Tran et al. [71] and $100 \mathrm{nM}$ for that reported by Cox and Ellington [68]. To assemble the aptasensors, screen-printed graphite electrodes were modified with diazonium salts produced in situ in order to introduce carboxylic groups on the electrode surface. Next, amine-ended aptamers were covalently immobilized on the surface. A comparison of the aptasensors revealed that both can be applied to lysozyme analysis in wine. However, somewhat improved sensitivity and a wider linear range were observed using the aptamer selected by Tran et al. [71] (linear range: $0.025-0.8 \mu \mathrm{M}$ ) with respect to the aptamer selected by Cox and Ellington [68] (linear range: 0.1-0.8 $\mu \mathrm{M}$ ). 


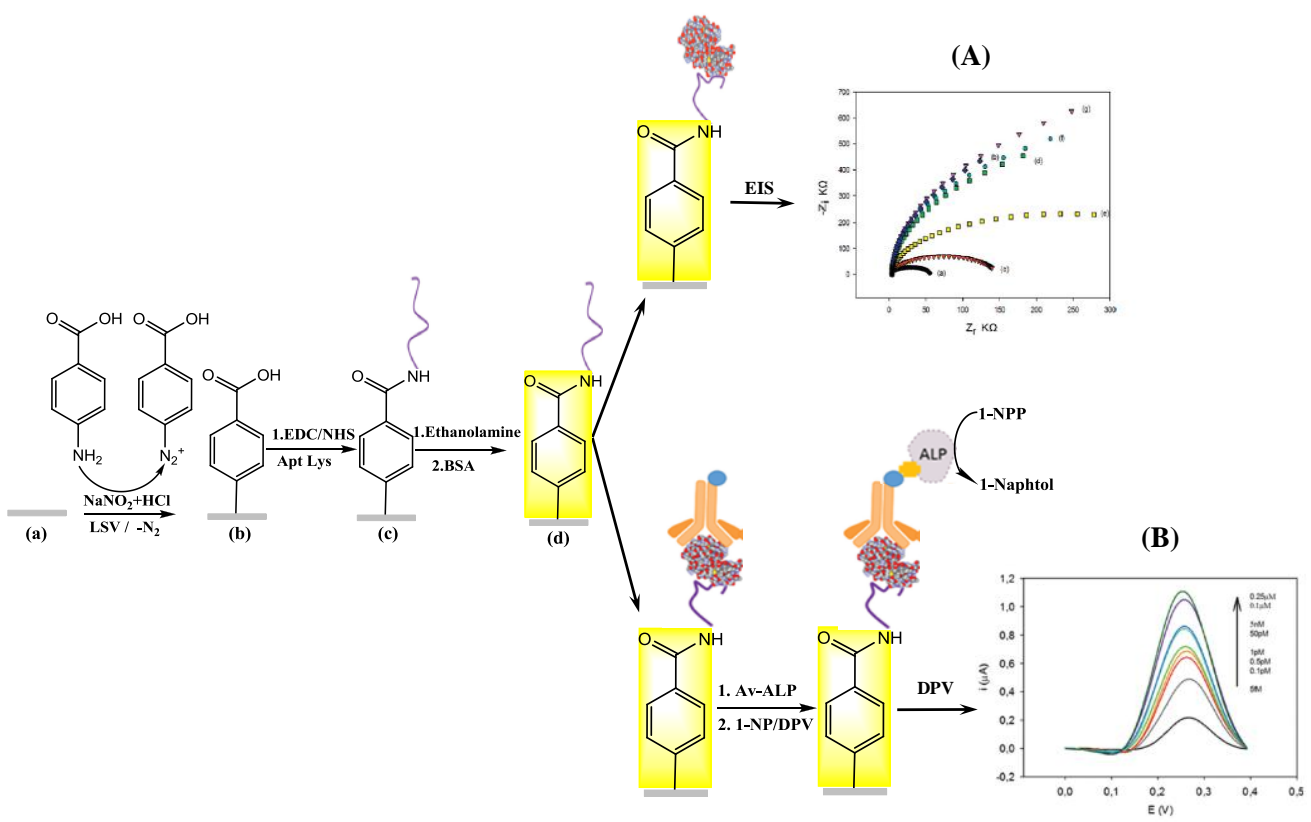

Figure 5. (A) Surface modification scheme and Nyquist plots for bare electrode (a), modified with diazonium salt (b), after EDC/NHS (c), functionalization with aptamer (d), after ethanolamine/BSA blocking (e) and after interaction with lysozyme (f) using PBS solutions containing $\left[\mathrm{Fe}(\mathrm{CN})_{6}\right]^{4-/ 3-}$ (2 mM) [63]; (B) surface modification and DPV signal after incubation with anti-lysozyme antibody and avidin-ALP coupling via biotin-avidin affinity for lysozyme sensing (reprint with permission from [44]).

Although simple, practical and label-free, these aptasensors lack the required sensitivity for more demanding applications, such as the detection of lysozyme in biological samples or of trace amounts of lysozyme in wine. Moving forward from the above direct assay, a sandwich between the surface linked aptamer, the captured lysozyme and a biotinylated anti-lysozyme antibody has been recently proposed to enhance the sensitivity of the sensor (Figure 4C) [44]. Labeling the assembly with avidin-modified alkaline phosphatase ("ALP") and the addition of the enzyme specific substrate 1-naphtyl phosphate ("1-NPP") (Figure 5B) allow the indirect quantification of lysozyme, by recording the current response upon the formation of the electrochemically-active product, 1-naphtol. This assay exhibited a detection limit of $4.3 \mathrm{fM}$ [44], a substantial improvement from the limit of detection of $0.1 \mu \mathrm{M}$ reported previously for the direct assay by EIS [63]. This improvement was due mainly to the power of signal amplification based on enzymatic labels, but also to the higher sensitivity of DPV compared to EIS. The gain in sensitivity comes with a cost in complexity, price per assay and inconvenience associated with limited enzyme stability; these should be all considered before choosing the "right" aptasensor design for a particular application.

Next to the direct and sandwich assays, competitive detection schemes (Figure 4D) allowed sensitive lysozyme sensing. The sensing principles applied rely on:

1. displacement of partially complementary and labeled DNA (ferrocene, AuNPs, etc.) from surface linked lysozyme binding aptamer (LBA) by lysozyme (signal-off sensor) $[46,47,91,98]$

2. displacement of dabcyl and metallic NPs-labeled lysozyme binding aptamers forming a host-guest complex with cyclodextrin in the presence of lysozyme and subsequent release of NPs in solution [89]

3. displacement of LBA from its methylene blue-tagged DNA complex in the presence of lysozyme, resulting in a conformational change of methylene blue-tagged DNA into a hairpin structure; this brings methylene blue closer to the electrode surface, leading to an increase of its signal (signal-on sensor) [90] 
4. displacement of LBA from its complex with DNA upon lysozyme addition (signal-off sensor) $[46,62,95]$

5. electrochemical stripping of lysozyme/quantum-dots complex [94]

6. desorption of lysozyme aptamer from rGO/Orange II-modified GCE, reversing the blocking effect and reestablishing efficient electron transfer from graphene-adsorbed aromatic dye Orange II [85]

Competitive detection schemes are typically used with regenerable sensors, where in order to revert to the characteristics of the original interface, the aptasensor needs simply to be re-incubated in fresh aptamer solution at the end of each measurement [62,89]. An ingenious detection strategy for multiple protein detection relied on immobilization of dabcyl-labeled-aptamer-modified metal nanoparticles (DLAPs) on a $\beta$-cyclodextrin-modified electrode by host-guest affinity [89]. Thrombin and lysozyme aptamers were labeled at the $3^{\prime}$ end with dabcyl, which is a typical "guest" for the $\beta$-cyclodextrin "host". At the $5^{\prime}$ end, the thrombin and lysozyme aptamers were labeled with CdS and $\mathrm{PbS}$ nanoparticles, respectively. The aptamers were captured at the electrode surface by host-guest interaction through their dabcyl label. Upon binding the target proteins, the aptamers were released from the $\beta$-cyclodextrin-coated surface. The detection of bound proteins was done through dissolution and electrochemical analysis of nanoparticle labels. Successful regeneration of initial aptasensing surface was demonstrated for eight regeneration cycles with no loss in activity, simply by incubating the sensors in $0.1 \mathrm{mM}$ DLAP solution for $30 \mathrm{~min}$. Moreover, the applicability of the aptasensor in the biomedical field was demonstrated by the analysis of human serum samples.

Note that competitive assay formats are particularly useful for devising generic interfaces that could be adapted to various analytes, allowing one to exploit generic amplification/detection schemes. All multi-analyte detection schemes developed so far that include lysozyme detection are based on competitive testing $[89,90,94,95]$. One of the most interesting approaches makes use simultaneously of both a "signal-on" and a "signal-off' mechanism for dual detection of lysozyme and interferon gamma (IFN- $\gamma$ ) [90]. The aptasensor is intended as an analytical tool in the diagnosis of acute leukemia and is built by immobilizing on a Au electrode two reporter DNA probes, one labeled with ferrocene ( $\mathrm{Fc})$ and the other one with methylene blue (MB). The Fc-probe and the MB-probe are designed to specifically hybridize with the IFN- $\gamma$ and lysozyme aptamer, respectively. In the presence of target proteins IFN- $\gamma$ and lysozyme, the aptamer is released from the respective DNA duplex, and the reporter probes suffer conformational changes, leading to decreased oxidation current for $\mathrm{FC}$ and increased oxidation current for MB, according to a "signal-off" and a "signal-on" mechanism, respectively.

Sensor arrays with hybridized DNA probes allow fulfilling the requirements of high-throughput and multi-analyte testing in the biomedical field. Consequently, starting from the aptasensors for dual analyte detection of lysozyme and adenosine, thrombin and interferon gamma $[89,90,94,95]$, the development of novel sensor arrays in conjunction with competitive detection schemes can be anticipated for the near future for the simultaneous electrochemical detection of various analytes, including lysozyme.

\subsection{Evaluation of Selectivity, Reproducibility and Storage Stability}

The selectivity of the electrochemical aptasensors was proven by challenging them with excess quantities of other proteins (e.g., bovine serum albumin, thrombin, immunoglobulin G, hemoglobin, myoglobin, casein, cytochrome C) tested either in individual solutions or in mixtures with lysozyme $[44,46,61,74,76,77,79,82,84,89-91]$. Some authors went further and proved also the selectivity of the lysozyme aptamer sequence by performing measurements with an identical sensor in which the aptamer was replaced by a scrambled DNA sequence $[81,82,87]$. For example, the current decrease in the adenine oxidation signal, taken as the analytical signal in the aptasensor developed by Rodriguez and Rivas [81], was only $2.7 \%$ with a scrambled sequence as compared to $87.6 \%$ for the lysozyme aptamer [81].

Most sensor platforms reported in the literature showed a good repeatability. In a typical example, the relative standard deviation of the determined charge transfer resistance was $4 \%$ for six replicate measurements of $5 \mu \mathrm{g} / \mathrm{mL}$ lysozyme, using the same impedimetric aptasensor [80]. 
Aptasensors' reproducibility was also good as proven by an RSD of around 5\% for several sensors fabricated in parallel [80]. These results are particularly important for complex sensors involving nanomaterials/nanocomposites and manual steps of preparation. For example, an RSD of $4.23 \%$ $(n=6)$ was reported for sensors based on GCE modified with graphene $/ \mathrm{Fe}_{2} \mathrm{O}_{3}$ and aptamer [84], while an RSD of $5.45 \%(n=10)$ was obtained for Au electrodes modified with a nanocomposite of hollow titanium dioxide nanoballs, three-dimensional reduced graphene oxide and polypyrrole $\left(\mathrm{TiO}_{2} / 3 \mathrm{D}-\mathrm{rGO} / \mathrm{PPy}\right)[74]$.

Moreover, most aptasensors reported satisfactory storage stability with less than a $16 \%$ decrease in the analytical signal at $4{ }^{\circ} \mathrm{C}$ over 2 weeks- 1 month $[44,47,74,76,91]$. While in some cases, sensor development targeted single-use [63], there were a few aptasensors for which multiple regeneration cycles were performed without affecting the magnitude of the analytical signal (less than 10\% decrease for $3-5$ regenerations) $[46,62,89,90]$. The reproducibility, storage stability and regeneration figures advanced in the literature for lysozyme aptasensors support their further development for commercial applications.

\subsection{Comparison of Electrochemical Lysozyme Sensors to Other Detection Schemes}

To put the performance of electrochemical aptasensors for lysozyme into perspective, Table 3 summarizes the sensing characteristics of other lysozyme biosensing platforms. When compared to all of the different electrochemical assays (Table 2), it is clear that electrochemical platforms are complementary to optical methods, such as SPR and even MALDI-TOF analysis. Surface-enhanced Raman spectroscopy (SERS) has currently the lowest reported detection limit, being $1 \mathrm{aM}$. The best performing electrochemical sensor showed a detection limit of $4.3 \mathrm{fM}$ [44] and is based on a sandwich format (Figure 3C). Interestingly, DPV on GCE modified with AuNPs and an iminodiacetic acid ligand proved to be also highly sensitive [98].

Table 3. Sensitivity of methods besides aptamer-based electrochemical ones for the detection of lysozyme.

\begin{tabular}{cccc}
\hline Detection Method & Ligand & Limit of Detection & Reference \\
\hline SPR & Aptamer & $0.5 \mathrm{nM}$ & {$[55]$} \\
DPV & IDA-Cu complex & $60 \mathrm{fM}$ & {$[98]$} \\
MALDI-TOF MS & Aptamer & $1 \mathrm{nM}$ & {$[99]$} \\
RLS & Aptamer & $1 \mathrm{pM}$ & {$[100]$} \\
ELISA & Antibody & $0.1 \mathrm{nM}$ & {$[32]$} \\
SERS & Aptamer & $1 \mathrm{aM}$ & {$[101]$} \\
Turbidimetry & Micrococcus lysodeikticus & $0.13 \mathrm{nM}$ & {$[102]$} \\
HPLC-FLD & - & $10 \mathrm{nM}$ & {$[103]$} \\
\hline
\end{tabular}

\section{Applications of Current Electrochemical Aptasensors for Lysozyme Sensing}

Choosing the optimum electrochemical detection for a particular practical application requires consideration of lysozyme levels typically encountered in the targeted type of sample, in conjunction with aptasensor simplicity, stability and any requirement for sensor regeneration. For clinical applications [73], testing the performance of the different sensors on real samples is of ultimate necessity. Approximately half of the electrochemical aptasensors for lysozyme developed so far were applied for real sample analysis (Table 2). Interestingly, all of these examples were reported in the last five years, in line with the general trend of increased focus on applications of electrochemical aptasensors observed, among others with aptasensors devoted to food safety. It is important to note that the levels of lysozyme in various types of real samples vary over a wide range, which are, however, within the detection range of aptasensors (Table 4). This proves the general applicability of the lysozyme aptasensing concept for a variety of samples. 
Table 4. Level of lysozyme determined using electrochemical aptasensors.

\begin{tabular}{ccc}
\hline Sample Analyzed & Lysozyme/ $\mu \mathbf{M}$ & Reference \\
\hline serum & $0.62-0.66$ & {$[90]$} \\
serum (healthy patient) & 0.22 & {$[73]$} \\
serum (IBD patient) & 0.78 & {$[73]$} \\
saliva (3 patient samples) & 5.17 & {$[77]$} \\
urine & $0.01-0.03$ & {$[91]$} \\
egg white & 218 & {$[60]$} \\
egg white & 239 & {$[77]$} \\
egg white & 263 & {$[46]$} \\
\hline
\end{tabular}

In most cases, egg white was the preferred matrix to prove the aptasensor's real-life applicability. Only two recent studies include the detection of lysozyme in spiked serum [89,90], while other reports concern saliva [77], urine [91], Ramos cancer cells [93] or wine [44,63]. This is linked to the complexity of samples: besides possible interfering compounds evaluated at an early stage during aptasensor development in buffer solutions, other challenges encountered in real matrices concern non-specific adsorption of sample components to the sensor surface; moreover, the high ionic strength of some samples can affect negatively the binding between lysozyme and aptamers. Various solutions have been devised for circumventing such problems. Efficient blocking of nonspecific adsorption is typically performed by incubation of Au-based aptasensors with short hydroxylated thiols, such as 6-mercapto-1-hexanol $[60,87,90]$, while, for carbon-based interfaces, blocking with $0.1 \%-1 \%$ solutions of BSA $[44,63,88]$ or IgG $[81]$ is preferred. Moreover, a washing step with buffer (sometimes containing 1\% Tween-20, $[87,95]$ ) performed after incubation of the aptasensor with the sample solution further alleviates problems due to non-specific binding $[44,46,60]$. To ensure reliable and quantitative determination of lysozyme in real samples, the simplest approach is to dilute samples with suitable electrolyte buffer in order to match the linear range of the aptasensor. However, this comes at the expense of possible errors associated with huge dilution factors. For example, many authors claimed high sensitivity for lysozyme detection, using egg white as the test sample. However, one could note that egg white contains the highest amount of lysozyme among all samples summarized in Table 3 , namely around $240 \mu \mathrm{M}(3.4 \mathrm{mg} / \mathrm{mL})$. Considering an aptasensor for which the upper linearity limit is set to $0.5 \mathrm{pM}$ [77], the estimated sample dilution factor required for lysozyme analysis is $4 \times 10^{8}$. Zhang et al. [75] compared the results obtained for several dilutions of egg white across the linear range of the aptasensor. Non-specific binding was observed for samples diluted to $50 \mathrm{ng} / \mathrm{mL}$ or higher concentrations, while diluting the sample to 1 or $10 \mathrm{ng} / \mathrm{mL}$ (dilution factor of $3 \times 10^{5}$ or higher) led to agreement between aptasensor responses for egg white and standard lysozyme solutions, respectively. As per the available literature data, dilution with buffer does represent an appropriate sample preparation step for serum, saliva or urine prior to analysis with the electrochemical aptasensors [78]. Instead, in wines, lysozyme binds to phenolic compounds [104], and a pre-treatment of wine with salt and surfactant was required to dissociate the complex. In another example, Ramos cancer cells analyzed by an aptamer-based electrochemical assay required trypsinization, centrifugation, washing, lysis and filtration through a $0.22-\mu \mathrm{m}$ membrane before lysozyme analysis [93]. What is still lacking to make these sensors accepted by clinicians and analytical laboratories is that besides some notable exceptions $[78,91]$, the studies did not include any comparison to standardized procedures, such as ELISA or HPLC, to confirm the results and validate the assay, and the accuracy was estimated solely on spiked samples and by comparison with levels reported in the literature for various types of samples.

\section{Conclusions and Perspectives}

Since the first aptamer for lysozyme had been proposed in 2001, a large amount of different electrochemical-based aptasensors have been developed over the years. Routinely, such sensors achieve a picomolar detection limit, with some even reaching the low femtomolar concentration range. 
There is an urgent need for moving beyond research by developing new concepts for achieving even better sensitivity and selectively, in order to bring some of the current sensors into real biomedical applications. Clearly, next steps in this direction might include:

(i) Sensor designs and use of materials compatible with large-scale manufacturing technologies for producing commercial aptasensors. The good analytical characteristics and reproducibility of lysozyme aptasensors produced by manual, multiple step procedures is promising. Several types of electrodes modified with proteins, mediators and nanomaterials, produced by screen-printing and ink-jet printing, are already available commercially and could be used as a generic basis for lysozyme and other aptasensors;

(ii) Experimental confirmation of the appropriate storage stability of the aptasensors for commercial purposes. Aptamers are inherently more stable compared to antibodies, for example; however, with the lysozyme aptasensors developed so far, storage stability beyond one month remains to be investigated;

(iii) Generic approaches appropriate for high throughput, multi-analyte testing. Lysozyme analysis might prove highly beneficial in the context of the multiplexed sensing of various disease biomarkers. Going in this direction, electrochemical aptasensors have been developed for dual detection of lysozyme and interferon gamma, aiming to diagnosis acute leukemia [90]. An illustration of the potential of generic platforms was provided by an aptasensor array based on eight screen-printed electrodes modified with AuNPs, coated with azide-ended thiols, onto which three different aptamers (for lysozyme, cocaine and thrombin) were immobilized by click-chemistry [60]. Reconciling the need for a short analysis time with the simultaneous demand for a high sensitivity of detection could come from new signal amplification strategies. Among others, recent approaches based on nanomaterials, such as graphene [105] or nanoceria [106], show promising potentialities;

(iv) Validation of novel aptasensors in comparison with methods currently used in clinical and analytical laboratories, such as ELISA and HPLC. So far, only three studies reported comparative results obtained with the aptasensor and by classical methods [73,78,91]. In the particular case of lysozyme, a comparison with other methods should be made with caution, since some methods measure the amount of enzymatically-active lysozyme, while others determine the total amount of protein. Moreover, differences between results provided by methods based on very different principles, e.g., chromatographic separation and affinity, are not uncommon [107].

Although many of the studies regarding lysozyme as a disease biomarker date back to the 1970s-1980s, currently, lysozyme analysis is not routinely performed in biochemical laboratories. Moreover, the most widely-used tests rely on ELISA analysis. Recent developments in biosensing research illustrate the applications of aptasensors for the dual detection of lysozyme and other important analytes, such as adenosine [95], thrombin [89,94] and interferon gamma [90]. The usefulness of aptasensors for serum analysis of patients with inflammatory bowel disease was recently demonstrated [73]. Consequently, new studies focused on the parallel analysis and correlations between disease biomarkers and lysozyme levels in biological samples are expected to boost research efforts tapping into the applicative potential of electrochemical aptasensing of lysozyme in the biomedical field.

Acknowledgments: Financial support from the Centre National de la Recherche Scientifique (CNRS), the Universite Lille 1, the Nord Pas de Calais region and the Institut Universitaire de France (IUF) is gratefully acknowledged. Q.W. thanks Chinese government for the China Scholarship Council (CSC) award for Ph.D. funding.

Author Contributions: Alina Vasilescu wrote the sensing part and parts linked to lysozyme aptamers. Qian Wang wrote Section 2 of the paper. Musen Li wrote Section 3 of the paper. Rabah Boukherroub wrote the conclusion and perspectives part and corrected the paper. Sabine Szunerits coordinated the work and wrote the introduction.

Conflicts of Interest: The authors declare no conflict of interest. 


\section{Abbreviations}

The following abbreviations are used in this manuscript:

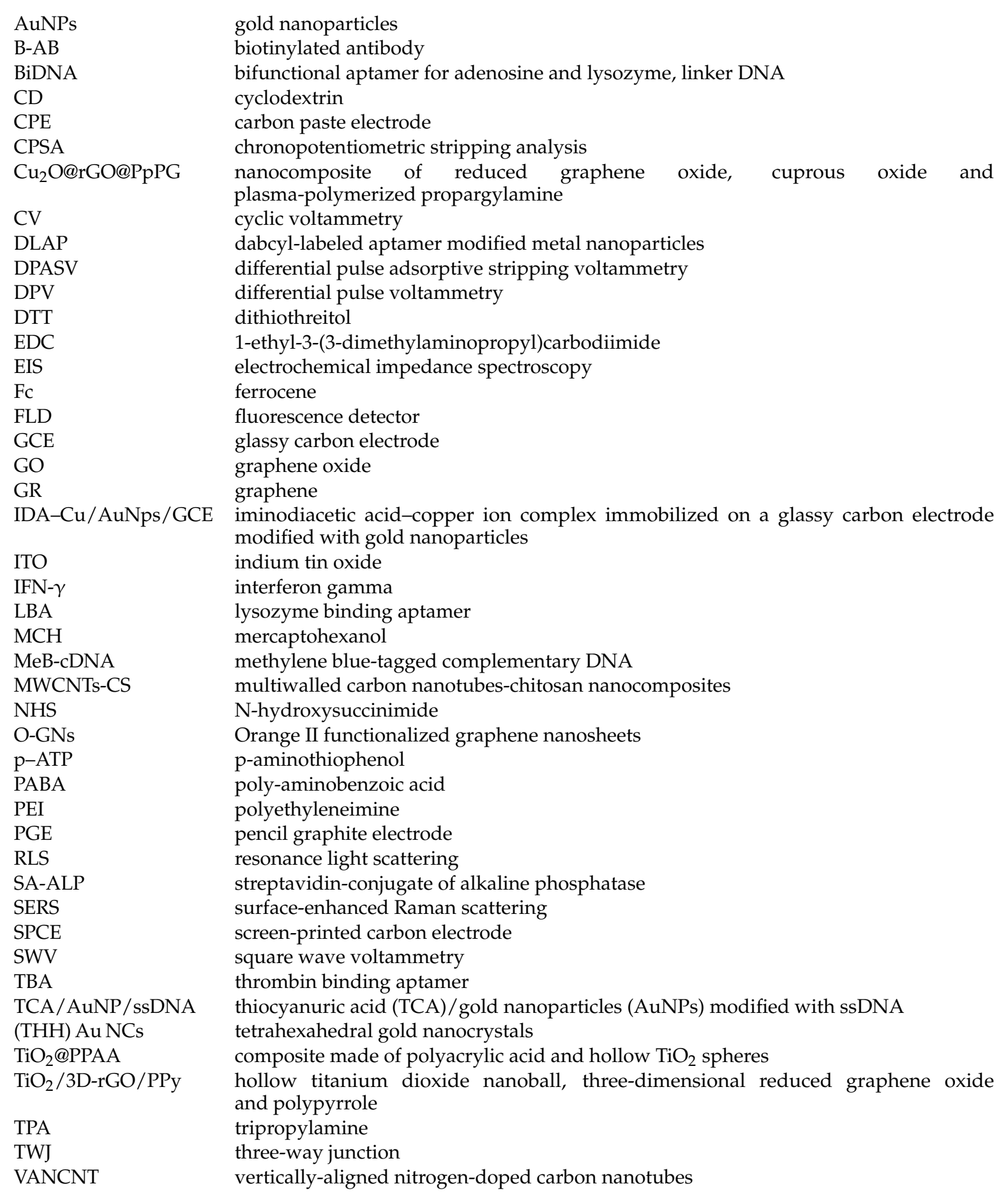

\section{References}

1. Laschtschenko, P. Uber die keimtötende und entwicklungshemmende Wirkung von Hühnereiweiß. Z. Hyg. Infekt. Krankh. 1909, 64, 419-427. [CrossRef]

2. Fleming, A. On a Remarkable Bacteriolytic Element Found in Tissues and Secretions. Proc. R. Soc. B Biol. Sci. 1922, 93, 306-317. [CrossRef]

3. Jollès, P. Recent Developments in the Study of Lysozymes. Angew. Chem. Int. Ed. Engl. 1964, 3, 28-36. [CrossRef] [PubMed] 
4. Cunningham, F.E.; Proctor, V.A.; Goetsch, S.J. Egg-white lysozyme as a food preservative: an overview. World's Poult. Sci. J. 1991, 47, 141-163. [CrossRef]

5. Callewaert, L.; Michiels, C.W. Lysozymes in the animal kingdom. J. Biosci. 2010, 35, 127-160. [CrossRef] [PubMed]

6. Jolles, P.; Jolles, J. What's new in lysozyme research? Always a model system, today as yesterday. Mol. Cell Biochem. 1984, 63, 165-189. [PubMed]

7. Blake, C.C.F.; Koenig, D.F.; Mair, G.A.; North, A.C.T.; Phillips, D.C.; Sarma, V.R. Structure of Hen Egg-White Lysozyme: A Three-dimensional Fourier Synthesis at $2 \AA$ Resolution. Nature 1965, 206, 757-761. [CrossRef] [PubMed]

8. Blake, C.C.; Mair, G.A.; North, A.C.; Phillips, D.C.; Sarma, V.R. On the conformation of the hen egg-white lysozyme molecule. Proc. R. Soc. Lond. B Biol. Sci. 1967, 167, 365-377. [CrossRef] [PubMed]

9. Miranker, A.; Radford, S.E.; Karplus, M.; Dobson, C.M. Demonstration by NMR of folding domains in lysozyme. Nature 1991, 349, 633-636. [CrossRef] [PubMed]

10. Dobson, C.M.; Evans, P.A.; Radford, S.E. Understanding how proteins fold: The lysozyme story so far. Trends Biochem. Sci. 1994, 19, 31-37. [CrossRef]

11. Merlini, G.; Bellotti, V. Lysozyme: a paradigmatic molecule for the investigation of protein structure, function and misfolding. Clin. Chim. Acta. 2005, 357, 168-172. [CrossRef] [PubMed]

12. Goda, S.; Takano, K.; Yamagata, Y.; Nagata, R.; Akutsu, H.; Maki, S.; Namba, K.; Yutani, K. Amyloid protofilament formation of hen egg lysozyme in highly concentrated ethanol solution. Protein Sci. 2000, 9, 369-375. [CrossRef] [PubMed]

13. Booth, D.R.; Sunde, M.; Bellotti, V.; Robinson, C.V.; Hutchinson, W.L.; Fraser, P.E.; Hawkins, P.N.; Dobson, C.M.; Radford, S.E.; Blake, C.C.; et al. Instability, unfolding and aggregation of human lysozyme variants underlying amyloid fibrillogenesis. Nature 1997, 385, 787-793. [CrossRef] [PubMed]

14. Swaminathan, R.; Ravi, V.K.; Kumar, S.; Kumar, M.V.; Chandra, N. Lysozyme: A model protein for amyloid research. Adv. Protein Chem. Struct. Biol. 2011, 84, 63-111. [PubMed]

15. Dumoulin, M.; Last, A.M.; Desmyter, A.; Decanniere, K.; Canet, D.; Larsson, G.; Spencer, A.; Archer, D.B.; Sasse, J.; Muyldermans, S.; et al. A camelid antibody fragment inhibits the formation of amyloid fibrils by human lysozyme. Nature 2003, 424, 783-788. [CrossRef] [PubMed]

16. Haas, M.; Moolenaar, F.; Meijer, D.K.; de Zeeuw, D. Specific drug delivery to the kidney. Cardiovasc. Drugs Ther. 2002, 16, 489-496. [CrossRef] [PubMed]

17. Dolman, M.E.; Harmsen, S.; Storm, G.; Hennink, W.E.; Kok, R.J. Drug targeting to the kidney: Advances in the active targeting of therapeutics to proximal tubular cells. Adv. Drug Deliv. Rev. 2010, 62, 1344-1357. [CrossRef] [PubMed]

18. Wasserfall, F.; Teuber, M. Action of egg white lysozyme on Clostridium tyrobutyricum. Appl. Environ. Microbiol. 1979, 38, 197-199. [PubMed]

19. Masschalck, B.; Michiels, C.W. Antimicrobial properties of lysozyme in relation to foodborne vegetative bacteria. Crit. Rev. Microbiol. 2003, 29, 191-214. [CrossRef] [PubMed]

20. Chen, K.; Han, S.-Y.; Zhang, B.; Li, M.; Sheng, W.-J. Development of lysozyme-combined antibacterial system to reduce sulfur dioxide and to stabilize Italian Riesling ice wine during aging process. Food Sci. Nutr. 2015, 3, 453-465. [CrossRef] [PubMed]

21. Peñas, E.; di Lorenzo, C.; Uberti, F.; Restani, P. Allergenic Proteins in Enology: A Review on Technological Applications and Safety Aspects. Molecules 2015, 20, 13144-13164. [CrossRef] [PubMed]

22. Weber, P.; Steinhart, H.; Paschke, A. Investigation of the allergenic potential of wines fined with various proteinogenic fining agents by ELISA. J. Agric. Food Chem. 2007, 55, 3127-3133. [CrossRef] [PubMed]

23. Weber, P.; Kratzin, H.; Brockow, K.; Ring, J.; Steinhart, H.; Paschke, A. Lysozyme in wine: A risk evaluation for consumers allergic to hen's egg. Mol. Nutr. Food Res. 2009, 53, 1469-1477. [CrossRef] [PubMed]

24. Schneider, N.; Werkmeister, K.; Becker, C.M.; Pischetsrieder, M. Prevalence and stability of lysozyme in cheese. Food Chem. 2011, 128, 145-151. [CrossRef] [PubMed]

25. Silvetti, T.; Brasca, M.; Lodi, R.; Vanoni, L.; Chiolerio, F.; Groot, M.; Bravi, A. Effects of Lysozyme on the Microbiological Stability and Organoleptic Properties of Unpasteurized Beer. J. Inst. Brew. 2010, 116, 33-40. [CrossRef]

26. Zimoch-Korzycka, A.; Jarmoluk, A. The use of chitosan, lysozyme, and the nano-silver as antimicrobial ingredients of edible protective hydrosols applied into the surface of meat. J. Food Sci. Technol. 2015, 52, 5996-6002. [CrossRef] [PubMed] 
27. Chander, R.; Lewis, N.F. Effect of lysozyme and sodium EDTA on shrimp microflora. Eur. J. Appl. Microbiol. Biotechnol. 1980, 10, 253-258. [CrossRef]

28. Humphrey, B.D.; Huang, N.; Klasing, K.C. Rice expressing lactoferrin and lysozyme has antibiotic-like properties when fed to chicks. J. Nutr. 2002, 132, 1214-1218. [PubMed]

29. Oliver, W.T.; Wells, J.E. Lysozyme as an alternative to antibiotics improves growth performance and small intestinal morphology in nursery pigs. J. Anim. Sci. 2013, 91, 3129-3136. [CrossRef] [PubMed]

30. Proctor, V.A.; Cunningham, F.E.; Fung, D.Y.C. The chemistry of lysozyme and its use as a food preservative and a pharmaceutical. CRC Crit. Rev. Food Sci. Nutr. 1988, 26, 359-395. [CrossRef] [PubMed]

31. Osserman, E.F.; Lawlor, D.P. Serum and urinary lysozyme (muramidase) in monocytic and monomyelocytic leukemia. J. Exp. Med. 1966, 124, 921-952. [CrossRef] [PubMed]

32. Immundiagnostik AG. Manual-Lysozyme ELISA for the in vitro Determination of Lysozyme in Serum, Urine and Liquor. Avaiable online: www.immundiagnostik.com/fileadmin/pdf/LYSOZYM_Serum\%20Urin\% 20Liq_K6902.pdf (accessed on 22 February 2016).

33. Porstmann, B.; Jung, K.; Schmechta, H.; Evers, U.; Pergande, M.; Porstmann, T.; Kramm, H.J.; Krause, H. Measurement of lysozyme in human body fluids: Comparison of various enzyme immunoassay techniques and their diagnostic application. Clin. Biochem. 1989, 22, 349-355. [CrossRef]

34. Lonnerdal, B. Biochemistry and physiological function of human milk proteins. Am. J. Clin. Nutr. 1985, 42, 1299-1317. [PubMed]

35. Hankiewicz, J.; Swierczek, E. Lysozyme in human body fluids. Clin. Chim. Acta 1974, 57, 205-209. [CrossRef]

36. Venge, P.; Foucard, T.; Henriksen, J.; Hakansson, L.; Kreuger, A. Serum-levels of lactoferrin, lysozyme and myeloperoxidase in normal, infection-prone and leukemic children. Clin. Chim. Acta 1984, 136, 121-130. [CrossRef]

37. Grieco, M.H.; Reddy, M.M.; Kothari, H.B.; Lange, M.; Buimovici-Klein, E.; William, D. Elevated beta 2-microglobulin and lysozyme levels in patients with acquired immune deficiency syndrome. Clin. Immunol. Immunopathol. 1984, 32, 174-184. [CrossRef]

38. Perillie, P.E.; Khan, K.; Finch, S.C. Serum lysozyme in pulmonary tuberculosis. Am. J. Med. Sci. 1973, 265, 297-302. [CrossRef] [PubMed]

39. Pascual, R.S.; Gee, J.B.; Finch, S.C. Usefulness of serum lysozyme measurement in diagnosis and evaluation of sarcoidosis. N. Engl. J. Med. 1973, 289, 1074-1076. [CrossRef] [PubMed]

40. Syrjanen, S.M.; Syrjanen, K.J. Lysozyme in the labial salivary glands of patients with rheumatoid arthritis. Z. Rheumatol. 1983, 42, 332-336. [PubMed]

41. Falchuk, K.R.; Perrotto, J.L.; Isselbacher, K.J. Serum lysozyme in Crohn's disease. A useful index of disease activity. Gastroenterology 1975, 69, 893-896. [PubMed]

42. Levinson, S.S.; Elin, R.J.; Yam, L. Light chain proteinuria and lysozymuria in a patient with acute monocytic leukemia. Clin. Chem. 2002, 48, 1131-1132. [PubMed]

43. Guder, W.G.; Hofmann, W. Clinical role of urinary low molecular weight proteins: their diagnostic and prognostic implications. Scand. J. Clin. Lab Investig. Suppl. 2008, 241, 95-98. [CrossRef] [PubMed]

44. Ocaña, C.; Hayat, A.; Mishra, R.; Vasilescu, A.; del Valle, M.; Marty, J.L. A novel electrochemical aptamer-antibody sandwich assay for lysozyme detection. Analyst 2015, 140, 4148-4153. [CrossRef] [PubMed]

45. Hun, X.; Chen, H.; Wang, W. Design of Ultrasensitive Chemiluminescence Detection of Lysozyme in Cancer Cells Based on Nicking Endonuclease Signal Amplification Technology. Biosens. Bioelectron. 2010, 26, 248-254. [CrossRef] [PubMed]

46. Chen, Z.; Li, L.; Tian, Y.; Mu, X.; Guo, L. Signal amplification architecture for electrochemical aptasensor based on network-like thiocyanuric acid/gold nanoparticle/ssDNA. Biosens. Bioelectron. 2012, 38, 37-42. [CrossRef] [PubMed]

47. Li, L.-D.; Chen, Z.-B.; Zhao, H.-Z.; Guo, L.; Mu, X. An Aptamer-Based Biosensor for the Detection of Lysozyme With Gold Nanoparticles Amplification. Sens. Actuators B Chem. 2010, 149, 110-115. [CrossRef]

48. Vasilescu, A.; Gaspar, S.; Gheorghiu, M.; David, S.; Dinca, V.; Peteu, S.; Wang, Q.; Li, M.; Boukherroub, R.; Szunerits, S. Surface Plasmon Resonance based sensing of lysozyme in serum on Micrococcus lysodeikticus-modified graphene oxide surfaces. Biosens. Bioelectron. 2016. in press. [CrossRef] [PubMed]

49. Weth, F.; Schroeder, T.; Buxtorf, U.P. Determination of lysozyme content in eggs and egg products using SDS-gel electrophoresis. Z. Lebensm. Unters. Forsch. 1988, 187, 541-545. [CrossRef] [PubMed] 
50. Galyean, R.D.; Cotterill, O.J. Ion-Exchange Chromatographic Determination of Lysozyme in Egg White. J. Food Sci. 1981, 46, 1827-1834. [CrossRef]

51. Daeschel, M.A.; Musafija-Jeknic, T.; Wu, Y.; Bizzarri, D.; Villa, A. High-Performance Liquid Chromatography Analysis of Lysozyme in Wine. Am. J. Enol. Vitic. 2002, 53, 154-157.

52. Francina, A.; Cloppet, H.; Guinet, R.; Rossi, M.; Guyotat, D.; Gentilhomme, O.; Richard, M. A rapid and sensitive non-competitive avidin-biotin immuno-enzymatic assay for lysozyme. J. Immunol. Methods 1986, 87, 267-272. [CrossRef]

53. Vidal, M.L.; Gautron, J.; Nys, Y. Development of an ELISA for quantifying lysozyme in hen egg white. J. Agric. Food Chem. 2005, 53, 2379-2385. [CrossRef] [PubMed]

54. Lacorn, M.G.C.; Haas-Lauterbach, S.; Immer, U. Sensitive lysozyme testing in red and white wine using the RIDASCREEN FAST Lysozyme ELISA. Bulletin de l'OIV 2010, 83, 507-511.

55. Subramanian, P.; Lesniewski, A.; Kaminska, I.; Vlandas, A.; Vasilescu, A.; Niedziolka-Jonsson, J.; Pichonat, E.; Happy, H.; Boukherroub, R.; Szunerits, S. Lysozyme detection on aptamer functionalized graphene-coated SPR interfaces. Biosens. Bioelectron. 2013, 50, 239-243. [CrossRef] [PubMed]

56. Mascini, M.; Palchetti, I.; Tombelli, S. Nucleic acid and peptide aptamers: fundamentals and bioanalytical aspects. Angew. Chem. Int. Ed. Engl. 2012, 51, 1316-1332. [CrossRef] [PubMed]

57. Sener, G.; Uzun, L.; Say, R.; Denizli, A. Use of molecular imprinted nanoparticles as biorecognition element on surface plasmon resonance sensor. Sens. Actuators B Chem. 2011, 160, 791-799. [CrossRef]

58. Wang, L.; Zhu, C.; Han, L.; Jin, L.; Zhou, M.; Dong, S. Label-free, regenerative and sensitive surface plasmon resonance and electrochemical aptasensors based on graphene. Chem. Commun. 2011, 47, 7794-7796. [CrossRef] [PubMed]

59. Mihai, I.; Vezeanu, A.; Polonschii, C.; Albu, C.; Radu, G.-L.; Vasilescu, A. Label-free detection of lysozyme in wines using an aptamer based biosensor and SPR detection. Sens. Actuators B Chem. 2015, 206, 198-204. [CrossRef]

60. Xie, D.; Li, C.; Shangguan, L.; Qi, H.; Xue, D.; Gao, Q.; Zhang, C. Click chemistry-assisted self-assembly of DNA aptamer on gold nanoparticles-modified screen-printed carbon electrodes for label-free electrochemical aptasensor. Sens. Actuators B Chem. 2014, 192, 558-564. [CrossRef]

61. Erdem, A.; Eksin, E.; Muti, M. Chitosan-graphene oxide based aptasensor for the impedimetric detection of lysozyme. Colloids Surf. B Biointerfaces 2014, 115, 205-211. [CrossRef] [PubMed]

62. Peng, Y.; Zhang, D.; Li, Y.; Qi, H.; Gao, Q.; Zhang, C. Label-free and sensitive faradic impedance aptasensor for the determination of lysozyme based on target-induced aptamer displacement. Biosens. Bioelectron. 2009, 25, 94-99. [CrossRef] [PubMed]

63. Ocaña, C.; Hayat, A.; Mishra, R.K.; Vasilescu, A.; Del Valle, M.; Marty, J.L. Label free aptasensor for Lysozyme detection: A comparison of the analytical performance of two aptamers. Bioelectrochemistry 2015, 105, 72-77. [CrossRef] [PubMed]

64. Rajendran, M.; Ellington, A.D. Selection of fluorescent aptamer beacons that light up in the presence of zinc. Anal. Bioanal. Chem. 2008, 390, 1067-1075. [CrossRef] [PubMed]

65. Shangguan, D.; Li, Y.; Tang, Z.; Cao, Z.C.; Chen, H.W.; Mallikaratchy, P.; Sefah, K.; Yang, C.J.; Tan, W. Aptamers evolved from live cells as effective molecular probes for cancer study. Proc. Natl. Acad. Sci. USA 2006, 103, 11838-11843. [CrossRef] [PubMed]

66. Bunka, D.H.; Stockley, P.G. Aptamers come of age at last. Nat. Rev. Microbiol. 2006, 4, 588-596. [CrossRef] [PubMed]

67. Iliuk, A.B.; Hu, L.; Tao, W.A. Aptamer in bioanalytical applications. Anal. Chem. 2011, 83, 4440-4452. [CrossRef] [PubMed]

68. Cox, J.C.; Ellington, A.D. Automated selection of anti-protein aptamers. Bioorg. Med. Chem. 2001, 9, 2525-2531. [CrossRef]

69. Cox, J.C.; Hayhurst, A.; Hesselberth, J.; Bayer, T.S.; Georgiou, G.; Ellington, A.D. Automated selection of aptamers against protein targets translated in vitro: From gene to aptamer. Nucleic. Acids Res. 2002, 30, e108. [CrossRef] [PubMed]

70. Kirby, R.; Cho, E.J.; Gehrke, B.; Bayer, T.; Park, Y.S.; Neikirk, D.P.; McDevitt, J.T.; Ellington, A.D. Aptamer-based sensor arrays for the detection and quantitation of proteins. Anal. Chem. 2004, 76, 4066-4075. [CrossRef] [PubMed] 
71. Tran, D.T.; Janssen, K.P.; Pollet, J.; Lammertyn, E.; Anne, J.; Van Schepdael, A.; Lammertyn, J. Selection and characterization of DNA aptamers for egg white lysozyme. Molecules 2010, 15, 1127-1140. [CrossRef] [PubMed]

72. Schoukroun-Barnes, L.R.; Glaser, E.P.; White, R.J. Heterogeneous Electrochemical Aptamer-Based Sensor Surfaces for Controlled Sensor Response. Langmuir 2015, 31, 6563-6569. [CrossRef] [PubMed]

73. Wang, Q.; Subramanian, P.; Schlechter, A.; Teblum, E.; Yemini, R.; Nessim, G.D.; Vasilescu, A.; Li, M.; Boukherroub, R.; Szunerits, S. Vertically aligned nitrogen-doped carbon nanotube carpet electrodes: Highly sensitive interfaces for the analysis of serum from patients with inflammatory bowel disease. ACS Appl. Mater. Interfaces 2016, 8, 9600-9609. [CrossRef] [PubMed]

74. Wang, M.; Zhai, S.; Ye, Z.; He, L.; Peng, D.; Feng, X.; Yang, Y.; Fang, S.; Zhang, H.; Zhang, Z. An electrochemical aptasensor based on a $\mathrm{TiO}_{2} /$ three-dimensional reduced graphene oxide/PPy nanocomposite for the sensitive detection of lysozyme. Dalton Trans. 2015, 44, 6473-6479. [CrossRef] [PubMed]

75. Zhang, Z.; Zhang, S.; He, L.; Peng, D.; Yan, F.; Wang, M.; Zhao, J.; Zhang, H.; Fang, S. Feasible electrochemical biosensor based on plasma polymerization-assisted composite of polyacrylic acid and hollow $\mathrm{TiO}_{2}$ spheres for sensitively detecting lysozyme. Biosens. Bioelectron. 2015, 74, 384-390. [CrossRef] [PubMed]

76. Chen, Z.; Li, L.; Zhao, H.; Guo, L.; Mu, X. Electrochemical impedance spectroscopy detection of lysozyme based on electrodeposited gold nanoparticles. Talanta 2011, 83, 1501-1506. [CrossRef] [PubMed]

77. Xiao, Y.; Wang, Y.; Wu, M.; Ma, X.; Yang, X. Graphene-based lysozyme binding aptamer nanocomposite for label-free and sensitive lysozyme sensing. J. Electroanal. Chem. 2013, 702, 49-55. [CrossRef]

78. Fang, S.; Dong, X.; Ji, H.; Liu, S.; Yan, F.; Peng, D.; He, L.; Wang, M.; Zhang, Z. Electrochemical aptasensor for lysozyme based on a gold electrode modified with a nanocomposite consisting of reduced graphene oxide, cuprous xide, and plasma-polymerized propargylamine. Microchim. Acta 2016, 183, 633-642. [CrossRef]

79. Chen, Z.; Guo, J.; Li, J.; Guo, L. Tetrahexahedral Au nanocrystals/aptamer based ultrasensitive electrochemical biosensor. RSC Adv. 2013, 3, 14385-14389. [CrossRef]

80. Rodriguez, M.C.; Kawde, A.-N.; Wang, J. Aptamer biosensor for label-free impedance spectroscopy detection of proteins based on recognition-induced switching of the surface charge. Chem. Commun. 2005, 34, 4267-4269. [CrossRef] [PubMed]

81. Rodriguez, M.C.; Rivas, G.A. Label-free electrochemical aptasensor for the detection of lysozyme. Talanta 2009, 78, 212-216. [CrossRef] [PubMed]

82. Rohrbach, F.; Karadeniz, H.; Erdem, A.; Famulok, M.; Mayer, G. Label-free impedimetric aptasensor for lysozyme detection based on carbon nanotube-modified screen-printed electrodes. Anal. Biochem. 2012, 421, 454-459. [CrossRef] [PubMed]

83. Du, M.; Yang, T.; Zhao, C.; Jiao, K. Electrochemical logic aptasensor based on graphene. Sens. Actuators B Chem. 2012, 169, 255-260. [CrossRef]

84. Du, M.; Yang, T.; Guo, X.; Zhong, L.; Jiao, K. Electrochemical synthesis of $\mathrm{Fe}_{2} \mathrm{O}_{3}$ on graphene matrix for indicator-free impedimetric aptasensing. Talanta 2013, 105, 229-234. [CrossRef] [PubMed]

85. Guo, Y.; Han, Y.; Guo, Y.; Dong, C. Graphene-Orange II composite nanosheets with electroactive functions as label-free aptasensing platform for "signal-on" detection of protein. Biosens. Bioelectron. 2013, 45, 95-101. [CrossRef] [PubMed]

86. Kawde, A.-N.; Rodriguez, M.C.; Lee, T.M.H.; Wang, J. Label-free bioelectronic detection of aptamer-protein interactions. Electrochem. Commun. 2005, 7, 537-540. [CrossRef]

87. Cheng, A.K.; Ge, B.; Yu, H.Z. Aptamer-based biosensors for label-free voltammetric detection of lysozyme. Anal. Chem. 2007, 79, 5158-5164. [CrossRef] [PubMed]

88. Du, Y.; Chen, C.; Li, B.; Zhou, M.; Wang, E.; Dong, S. Layer-by-layer electrochemical biosensor with aptamer-appended active polyelectrolyte multilayer for sensitive protein determination. Biosens. Bioelectron. 2010, 25, 1902-1907. [CrossRef] [PubMed]

89. Cheng, L.; Zhang, J.; Lin, Y.; Wang, Q.; Zhang, X.; Ding, Y.; Cui, H.; Fan, H. An electrochemical molecular recognition-based aptasensor for multiple protein detection. Anal. Biochem. 2015, 491, 31-36. [CrossRef] [PubMed]

90. Xia, J.; Song, D.; Wang, Z.; Zhang, F.; Yang, M.; Gui, R.; Xia, L.; Bi, S.; Xia, Y.; Li, Y.; et al. Single electrode biosensor for simultaneous determination of interferon gamma and lysozyme. Biosens. Bioelectron. 2015, 68, 55-61. [CrossRef] [PubMed]

91. Chen, Z.; Guo, J. A reagentless signal-off architecture for electrochemical aptasensor for the detection of lysozyme. Electrochim. Acta 2013, 111, 916-920. [CrossRef] 
92. Liu, D.Y.; Zhao, Y.; He, X.W.; Yin, X.B. Electrochemical aptasensor using the tripropylamine oxidation to probe intramolecular displacement between target and complementary nucleotide for protein array. Biosens. Bioelectron. 2011, 26, 2905-2910. [CrossRef] [PubMed]

93. Zhang, H.; Fang, C.; Zhang, S. Ultrasensitive electrochemical analysis of two analytes by using an autonomous DNA machine that works in a two-cycle mode. Chemistry 2011, 17, 7531-7537. [CrossRef] [PubMed]

94. Hansen, J.A.; Wang, J.; Kawde, A.N.; Xiang, Y.; Gothelf, K.V.; Collins, G. Quantum-dot/aptamer-based ultrasensitive multi-analyte electrochemical biosensor. J. Am. Chem. Soc. 2006, 128, 2228-2229. [CrossRef] [PubMed]

95. Deng, C.; Chen, J.; Nie, L.; Nie, Z.; Yao, S. Sensitive bifunctional aptamer-based electrochemical biosensor for small molecules and protein. Anal. Chem. 2009, 81, 9972-9978. [CrossRef] [PubMed]

96. Xia, Y.; Gan, S.; Xu, Q.; Qiu, X.; Gao, P.; Huang, S. A three-way junction aptasensor for lysozyme detection. Biosens. Bioelectron. 2013, 39, 250-254. [CrossRef] [PubMed]

97. Vasilescu, A.; Marty, J.-L. Electrochemical aptasensors for the assessment of food quality and safety. Trends Anal. Chem. 2016, 79, 60-70. [CrossRef]

98. Arabzadeh, A.; Salimi, A. Novel voltammetric and impedimetric sensor for femtomolar determination of lysozyme based on metal-chelate affinity immobilized onto gold nanoparticles. Biosens. Bioelectron. 2015, 74, 270-276. [CrossRef] [PubMed]

99. Zhang, X.; Zhu, S.; Xiong, Y.; Deng, C.; Zhang, X. Development of a MALDI-TOF MS strategy for the high-throughput analysis of biomarkers: On-target aptamer immobilization and laser-accelerated proteolysis. Angew. Chem. Int. Ed. Engl. 2013, 52, 6055-6058. [CrossRef] [PubMed]

100. Chen, F.; Cai, C.; Chen, X.; Chen, C. "Click on the bidirectional switch": The aptasensor for simultaneous detection of lysozyme and ATP with high sensitivity and high selectivity. Sci. Rep. 2016, 6, 18814. [CrossRef] [PubMed]

101. He, P.; Zhang, Y.; Liu, L.; Qiao, W.; Zhang, S. Ultrasensitive SERS Detection of Lysozyme by a Target-Triggering Multiple Cycle Amplification Strategy Based on a Gold Substrate. Chem. Eur. J. 2013, 19, 7452-7460. [CrossRef] [PubMed]

102. Liao, Y.H.; Brown, M.B.; Martin, G.P. Turbidimetric and HPLC assays for the determination of formulated lysozyme activity. J. Pharm. Pharmacol. 2001, 53, 549-554. [CrossRef] [PubMed]

103. Determination of Lysozyme in Wine Using High-Performance Liquid Chromatography. Available online: http://www.oiv.int/public/medias/2553/oiv-ma-as315--25-en.pdf (accessed on 22 March 2016).

104. Guzzo, F.; Cappello, M.S.; Azzolini, M.; Tosi, E.; Zapparoli, G. The inhibitory effects of wine phenolics on lysozyme activity against lactic acid bacteria. Int. J. Food Microbiol. 2011, 148, 184-190. [CrossRef] [PubMed]

105. Loo, A.H.; Bonanni, A.; Pumera, M. Mycotoxin aptasensing amplification by using inherently electroactive graphene-oxide nanoplatelet labels ChemElectroChem 2015, 2, 743-747. [CrossRef]

106. Bulbul, G.; Hayat, A.; Andreescu, S. A generic amplification strategy for electrochemical aptasensors using a non-enzymatic nanoceria tag. Nanoscale 2015, 7, 13230-13238. [CrossRef] [PubMed]

107. Barbara Kerkaert, B.; Mestdagh, F.; De Meulenaer, B. Detection of hen's egg white lysozyme in food: Comparison between a sensitive HPLC and a commercial ELISA method. Food Chem. 2010, 120, 580-584. [CrossRef]

(C) 2016 by the authors; licensee MDPI, Basel, Switzerland. This article is an open access article distributed under the terms and conditions of the Creative Commons Attribution (CC-BY) license (http://creativecommons.org/licenses/by/4.0/). 